\title{
Radiotracer Assay of Microbial Processes in Petroleum Reservoirs
}

\author{
Tamara N Nazina*, Natalya M Shestakova, Valeriy S Ivoilov, Nadezda K Kostrukova, Sergey S Belyaev and \\ Mikhail V Ivanov \\ Department of Microbial Biogeochemistry and Biogeotechnology, Winogradsky Institute of Microbiology, Russia
}

Submission: February 17, 2017; Published: March 14, 2017

*Corresponding author: Tamara N Nazina, Winogradsky Institute of Microbiology, Research Center of Biotechnology, Russian Academy of Sciences, prospect 60-letiya Oktyabrya, 7/2 Moscow, 117312, Russia, Tel: +7-499-135-03-41; Email: nazina@inmi.ru

\begin{abstract}
The paper provides quantitative characterization of the rates of aerobic (methane oxidation) and anaerobic (sulfate reduction, methanogenesis, acetogenesis) biogeochemical processes in oilfields with various physicochemical and hydrodynamic conditions and type of oil-bearing rocks determined using radioactive labeled substrates. Importantly, detection of a specific physiological group of microorganisms by cultural or molecular techniques does not automatically imply bacterial activity in environmental samples. For reliable detection of contemporary biogeochemical processes, a combination of radioisotope methods with physicochemical, biogeochemical, microbiological, and molecular biological techniques is required.
\end{abstract}

Keywords: Petroleum reservoirs; Methanogenesis; Acetogenesis ; Sulfate reduction; Radioisotope tracing methods

\section{Introduction}

Microbial communities of petroleum reservoirs are among the most ancient biocenoses on Earth. The study of these communities is necessary to gain knowledge on the evolution of the biosphere and on the genesis and transformation of petroleum hydrocarbons. Little is known concerning deep subterranean flows of matter.

Oilfield microbial communities exist under conditions of hampered exchange of water and mass and at a constant temperature; they are independent of the modern atmosphere and sunlight and may be considered closed or semi-closed systems. Crude oil is the main source of organic matter in this ecosystem. Microbial growth in reservoirs can be limited by the low content of phosphate and ammonium nutrients [1,2]. Formation waters usually contain no dissolved oxygen and nitrate, while sulfate and other oxidized sulfur compounds are present, as well as carbonate. Sulfate reduction, methanogenesis, and acetogenesis are therefore probably the major metabolic processes occurring in such ecosystems. Since microbial processes are very slow due to low water exchange and scarcity of biogenic elements, oil in the reservoirs is preserved for geological periods. Activation of water exchange resulting from geological processes or anthropogenic activity returns the buried organic matter of petroleum into the biogeochemical cycles. Present-time biogenic processes of petroleum transformation and the relevant microorganisms are relatively poorly studied.

Radiotracer techniques may be used for integral assessment of the activity of a microbial community as a whole. The techniques for determination of the rates of terminal stages of petroleum biodegradation (sulfate reduction and methanogenesis) using radioactively labeled $\mathrm{Na}_{2}{ }^{35} \mathrm{SO}_{4}, \mathrm{NaH}^{14} \mathrm{CO}_{3}$, and ${ }^{14} \mathrm{CH}_{3} \mathrm{COONa}$ have been developed by Russian researchers - Ivanov MV (1956) [3], Belyaev SS [4,5] and co-workers. Introduction of radiolabeled substrates $\left({ }^{35} \mathrm{SO}_{4}{ }^{2},{ }^{14} \mathrm{CO}_{2},{ }^{14} \mathrm{CH}_{3} \mathrm{COOH}\right)$ into formation water results in synthesis of labeled radioactive products and makes it possible to assess the rates of the relevant processes:

$$
\begin{aligned}
& \text { Sulfate reduction: }{ }^{35} \mathrm{SO}_{4}{ }^{2-}+\mathrm{Corg} \rightarrow{ }^{35} \mathrm{~S}^{2-}+\mathrm{CO}_{2} \\
& \text { Methanogenesis: }{ }^{14} \mathrm{CO}_{2}+\mathrm{H}_{2} \rightarrow{ }^{14} \mathrm{CH}_{4}+\mathrm{H}_{2} \mathrm{O} \\
& \qquad{ }^{14} \mathrm{CH}_{3} \mathrm{COOH} \rightarrow{ }^{14} \mathrm{CH}_{4}+\mathrm{CO}_{2}
\end{aligned}
$$

Oxidation of methane: ${ }^{14} \mathrm{CH}_{4}+\mathrm{O}_{2} \rightarrow{ }^{14} \mathrm{CO}_{2}+\mathrm{H}_{2} \mathrm{O}$

Acetogenesis: ${ }^{14} \mathrm{CO}_{2}+\mathrm{H}_{2} \rightarrow{ }^{14} \mathrm{CH}_{3}{ }^{14} \mathrm{COOH}$

The aim of this work was to summarize the results of quantitative assessment of microbial geochemical activity in 
petroleum reservoirs with different physicochemical conditions and collector properties. Rozanova et al. [6] were the first who used radioisotope technique to measure the rate of sulfate reduction in petroleum reservoirs. Quantitative characteristics of anaerobic biogenic processes in petroleum reservoirs are presented in Table 1. Sulfate reduction and methanogenesis were registered by radioisotope methods in the layers with temperatures from 17 to $80{ }^{\circ} \mathrm{C}$ and salinity of up to $287 \mathrm{~g} \mathrm{~L}^{-1}$. In petroleum reservoirs exploited with water-flooding, the rates of both processes were highest in the water from the near-bottom zone of injection wells; they were therefore concentrated in the zone of petroleum oxidation (Table 1). Our results demonstrate that in water-flooded petroleum reservoirs, both aerobicanaerobic and anaerobic processes are important in petroleum biodegradation [7-11].

Table 1: Rates of sulfate reduction and methanogenesis in formation waters from petroleum reservoirs determined by radioisotope tracing methods.

\begin{tabular}{|c|c|c|c|c|c|c|c|c|}
\hline \multirow{2}{*}{ Oil Field, country } & \multirow{2}{*}{$\begin{array}{l}\text { Salinity, } \\
\mathrm{g} \mathrm{L}^{-1}\end{array}$} & \multirow{2}{*}{$\begin{array}{c}\text { Temperature, } \\
{ }^{0} \mathrm{C}\end{array}$} & \multirow{2}{*}{$\begin{array}{l}\mathrm{SO}_{4}^{2-} \\
\mathrm{mg} \mathrm{L}^{-1}\end{array}$} & \multirow{2}{*}{$\begin{array}{l}\text { Acetate, } \\
\text { mg L }^{-1}\end{array}$} & \multirow{2}{*}{$\begin{array}{c}\text { Sulfate } \\
\text { reduction } \\
\text { rate, } \mu \mathrm{g} S 2 \text { - } \\
\mathbf{L}^{-1} \text { day }^{-1}\end{array}$} & \multicolumn{2}{|c|}{$\begin{array}{c}\text { Methanogenesis rate, } \mu \mathrm{g} \mathrm{CH}_{4} \\
\mathrm{~L}^{-1} \text { day }^{-1}\end{array}$} & \multirow{2}{*}{ Reference } \\
\hline & & & & & & $\begin{array}{c}\text { From } \\
\mathrm{NaH}^{14} \mathrm{CO}_{3}\end{array}$ & $\begin{array}{c}\text { From } \\
2-{ }^{14} \text { C-acetate }\end{array}$ & \\
\hline \multicolumn{9}{|c|}{ Petroleum Reservoirs with Sandstone Oil-bearing Collectors } \\
\hline \multirow{2}{*}{ Binagady, Azerbaijan } & $16-50$ & 34 & $48-3340$ & Н.д. & $0-817.3$ & $\mathrm{Nd}$ & $\mathrm{Nd}$ & [6] \\
\hline & $17-46$ & $29-34$ & $6-550$ & $20-199$ & $72-285$ & $49.9-681.8$ & $0.42-6.58$ & [7] \\
\hline $\begin{array}{l}\text { Bondyuzhskoe, } \\
\text { Russia }\end{array}$ & $8-292$ & $30-40$ & $17-69$ & $0.3-29.1$ & $0.01-2.66^{*}$ & $0-0.40$ & $0-0.07$ & {$[26,43,44,51]$} \\
\hline \multirow{2}{*}{ Daqing, China } & $2.6-3.0^{*}$ & 30 & $0-72$ & $0-61^{*}$ & $\begin{array}{l}16.63- \\
1027^{*}\end{array}$ & $0.49-169.2^{*}$ & $0-1163.87^{*}$ & \multirow[t]{2}{*}{ [10] } \\
\hline & $3.7-4.6$ & 46 & $12-24$ & $9-408$ & $0-3.611$ & $0-0.003$ & $0-7.28$ & \\
\hline \multirow{3}{*}{ Mykhpaiskoe, Russia } & $15-28$ & 60 & $0.1-5.1$ & $18-277$ & $0.001-0.07$ & $0.125-0.74$ & $0.22-6.01$ & {$[44]$} \\
\hline & \multirow{2}{*}{$15-28$} & \multirow{2}{*}{60} & \multirow{2}{*}{$0-2$} & $30-128^{*}$ & $0-1.218^{*}$ & $0-49.19^{*}$ & $0-1.9^{*}$ & \multirow{2}{*}{ [8] } \\
\hline & & & & $18-277$ & $0.008-0.48$ & $0.36-1.20$ & $0.032-8.42$ & \\
\hline Talinskoe, Russia & $8-20$ & $70-80$ & $0-17$ & $1-30$ & $0-0.001$ & $0.123-0.406$ & $0.29-0.44$ & [8] \\
\hline Savyiskoe, Russia & $11-177$ & 60 & $2-5$ & $10-21$ & $0.5-3.06$ & $1.75-6.37$ & $0.02-0.18$ & [55] \\
\hline $\begin{array}{l}\text { Mamontovskoe, } \\
\text { Russia }\end{array}$ & $4.5-21$ & 60 & $8.6-24.8$ & $56-800$ & $0-5.8$ & $0.002-0.08$ & $0-0.02$ & {$[56]$} \\
\hline Liaohe, China & $3-4$ & 60 & $0-1$ & $20-120$ & $0-1.118$ & 0 & $0-0.628$ & [57] \\
\hline \multirow{3}{*}{ Samotlor, Russia } & $7.7-20.5$ & 60 & $0-25$ & $5-544$ & $\begin{array}{l}0.001- \\
0.093\end{array}$ & $0-0.480$ & $0-0.146$ & \multirow{3}{*}{ [28] } \\
\hline & $6.7-39.7$ & $70-72$ & $0-30$ & $0-10$ & 0.001-0.49 & $0.001-0.248$ & $0-0.177$ & \\
\hline & $24.3-32.8$ & $84-85$ & $0-14$ & $0-544$ & $0-0.055^{* *}$ & $0.55-1.4^{* *}$ & $0-0.3^{* *}$ & \\
\hline $\begin{array}{l}\text { White Tiger, } \\
\text { Vietnam }\end{array}$ & $2-7$ & $70-100$ & 2567 & $1-95$ & $\begin{array}{l}12.94^{*} \text { (at } \\
\left.60^{\circ} \mathrm{C}\right)\end{array}$ & $\mathrm{Nd}$ & $\mathrm{Nd}$ & [24] \\
\hline \multicolumn{8}{|l|}{$\begin{array}{c}\text { Romashkinskoe, } \\
\text { Russia }\end{array}$} & \multirow{3}{*}{ [58] } \\
\hline $\begin{array}{c}\text { Severo- } \\
\text { Aznakaevskaya bed }\end{array}$ & $137-287$ & $30-35$ & $40-100$ & $0-40$ & $0-280$ & $0-0.07$ & $0-0.09$ & \\
\hline Chishminskaya bed & $11-122$ & $30-35$ & $0-50$ & $0-40$ & $0-10$ & $0-0.06$ & $0-0.08$ & \\
\hline \multicolumn{9}{|l|}{ Dagang, China } \\
\hline Kongdian bed & $5.8-6.6$ & 59 & 0 & $0-5$ & $\begin{array}{l}0.002- \\
18.94\end{array}$ & $0-1.595$ & $0-14.73^{*}$ & [59] \\
\hline Gangxi bed & $5.2-8.6$ & $35-54$ & $44-61$ & $0.5-15$ & $3.32-7.88$ & 0 & $0.02-0.36$ & [29] \\
\hline $\begin{array}{l}\text { Chernoozerskoe, } \\
\text { Russia }\end{array}$ & $239-245$ & 25 & $227-607$ & $7-20$ & $0.016-0.20$ & $0-0.01$ & $0-0.28$ & This study \\
\hline $\begin{array}{c}\text { Uzhno- } \\
\text { Suncheleevskoe, } \\
\text { Russia }\end{array}$ & $234-240$ & 23 & $246-501$ & $1-13$ & $0-0.14$ & $0.10-0.11$ & $0-0.03$ & This study \\
\hline
\end{tabular}

${ }^{*}$ Rate in water from the near-bottom zone of injection well; other data apply to formation water from production wells. ${ }^{* *}$ Rate at $80{ }^{\circ} \mathrm{C}$. Nd -no data. 
Rates of microbial processes in petroleum reservoirs with carbonate oil-bearing rocks

The major role of bacterial sulfate reduction in sulfide formation in carbonate petroleum collectors containing sulfate is presently established [12-15]. For example, sulfate reduction was the dominant terminal process in the Bavlinskoe oilfield and in beds 302 and 303 of the Romashkinskoe oilfield, where the levels of sulfate and sulfide in the water are high; its rate reached $171-237 \mu \mathrm{g} \mathrm{S}^{2-} \mathrm{L}^{-1}$ day ${ }^{-1}$, while the rate of methanogenesis was 10 100 times lower [13-15]. Sulfate reduction was limited by the absence of available organic substrates and biogenic elements (nitrogen, phosphorus, and iron). Amendment of isolated formation water samples with hydrogen, acetate, benzoate, hexadecane, or especially methane resulted in stimulation of sulfate reduction (Figure 1) [9]. Thus, apart from $\mathrm{H}_{2} / \mathrm{CO}_{2}$, lower alcohols, and volatile fatty acids, hexadecane and methane can also act as carbon and energy sources for sulfidogenic communities of the oil reservoirs with carbonate collectors. This was confirmed by obtaining sulfidogenic enrichments on these substrates and on molasses $[9,16]$.

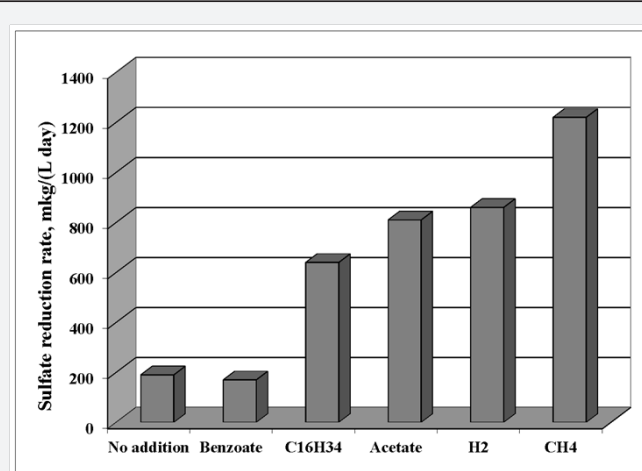

Figure 1: Effect of various additions on sulfate reduction rate in water sample from production well of the bed 302 with carbonate collector of the Romashkinskoe oilfield.

Sulfate-reducing prokaryotes identified in the water samples from carbonate and terrigenous oilfields are listed by Gieg et al. [17]. The range of substrates utilized by sulfidogenic microbial communities isolated from petroleum reservoirs included $\mathrm{H}_{2} /$ $\mathrm{CO}_{2}$, lactate, formate, propionate, butyrate, and other fatty acids (up to $\mathrm{C}_{7}$ ), ethanol, methanol, glucose, peptone, benzoate, ketones, molasses, and crude oil $[1,17]$. Most pure cultures of sulfate-reducing bacteria isolated from petroleum reservoirs cannot grow on hydrocarbons. A range of these bacteria are able to grow autotrophically on $\mathrm{H}_{2} / \mathrm{CO}_{2}$ (Desulfacinum infernum, Desulfacinum subterraneum, Desulfotomaculum sp, Desulfotomaculum kuznetsovii, Desulfomicrobium apsheronum, Desulfobacterium cetonicum) or in the presence of acetate or yeast extract as additional carbon sources. Organotrophic hyperthermophilic archaea Archaeoglobus fulgidus isolated from petroleum reservoirs of the North Sea and Alaska grow on complex substrates and oxidize lactate completely. Recently, $A$. fulgidus was shown to be capable of utilizing alkenes and related fatty acids with thiosulfate as an electron acceptor [18]. Sulfate, sulfite, and thiosulfate are the most common electron acceptors for sulfate-reducing bacteria; some organisms are also able to reduce elemental sulfur.

A search for anaerobic organisms decomposing hydrocarbons and petroleum is presently under way. Pure cultures of hydrocarbon-utilizing sulfate-reducing bacteria were initially isolated from terrestrial and marine environments by Widdel and coworkers [19,20]. Anaerobic biodegradation of $n$-alkanes is now a well-documented process that has been demonstrated under nitrate-reducing, sulfate-reducing and methanogenic conditions [21-23]. Most of the microorganisms were isolated from terrestrial environments. Mesophilic sulfidogenic enrichments growing on hexadecane were obtained from a carbonate collector of the Romashkinskoe reservoir (bed 302, Russia) [9]. A thermophilic sulfidogenic enrichment utilizing crude oil was also isolated from the White Tiger reservoir (Vietnam) [24]. A pure culture of the sulfate-reducing bacterium Desulfoglaeba alkanexedens utilizing $\mathrm{C}_{6}-\mathrm{C}_{12} n$-alkanes was isolated from an oil reservoir in Oklahoma (United States) [16]. These works demonstrate abundance of sulfate-reducing bacteria capable of anaerobic hydrocarbon degradation in the reservoirs with temperatures from 18 to $80^{\circ} \mathrm{C}$. A range of special reviews was devoted to the genes governing hydrocarbon degradation by anaerobic bacteria [21,25]; this problem is, however, beyond the scope of the present study.

\section{Rates of microbial processes in terrigenous petroleum reservoirs}

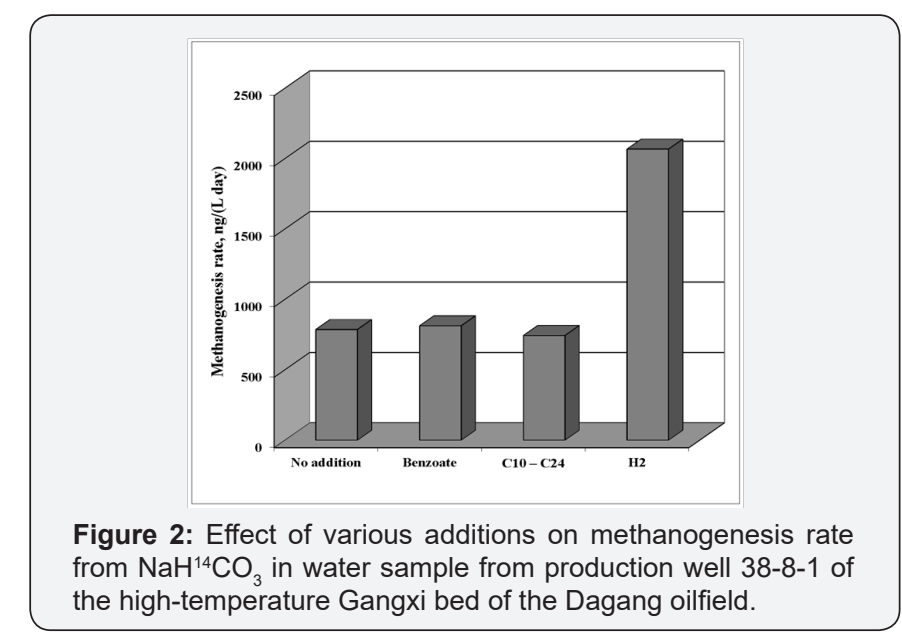

In terrigenous petroleum reservoirs with sandstone collectors and low sulfate content in formation water, methanogenesis is the predominant process [26,27]. In sulfate-containing formation water both processes proceed simultaneously with different rates. The absence of sulfate limited sulfate reduction in the waters of Mykhpaiskoe and Samotlor oilfields $[8,28]$. Injection of sulfate-enriched water stimulated sulfidogenesis in the Binagady and Daqing oilfields, where $\mathrm{SO}_{4}{ }^{2-}$ and $\mathrm{H}_{2} \mathrm{~S}$ were initially absent $[6,10]$. Addition of $\mathrm{H}_{2}$, acetate, or crude oil stimulated methane production in 
formation water samples from the Mykhpaiskoe (Russia) and Dagang oilfields (Figure 2) [8,29]. Data on extremely high rates of microbial processes in oilfields registered in the course of application of various MEOR technologies were not included In Table $1[11,14]$. Addition of $\mathrm{H}_{2} / \mathrm{CO}_{2}$ with acetate to the water samples of the Rinkon reservoir (California, United States) had a more pronounced effect on methanogenesis than addition of $\mathrm{H}_{2} / \mathrm{CO}_{2}$ alone [30,31]. These results demonstrate that, in spite of abundant petroleum organic matter, available utilizable sources of carbon and energy are scarce in petroleum reservoirs. The lowest rates of microbial processes were observed at heavy oil deposits (Chernoozerskoe and Yuzhno-Suncheleevskoe, Russia) with highly mineralized formation waters, which were exploited without water-flooding (Table 1).

Gieg and co-authors [31] estimated the rates of sulfate reduction in two high-temperature distinct oilfields on the North Slope of Alaska (designated Fields A and B). Rate measurements revealed that sulfate reduction was an important electron accepting process in Field A (6-807mmol S L $\mathrm{L}^{-1}$ day $\left.^{-1}\right)$, but of lesser consequence in Field $B\left(0.1-10 \mathrm{mmol} \mathrm{S} \mathrm{L}^{-1}\right.$ day $\left.^{-1}\right)$. The signature metabolites of anaerobic hydrocarbon degradation were detected in produced water from the two oilfields offering evidence of in situ biodegradation activity. A methanogenic consortium obtained from Field B did showed a strong functional similarity with the high-temperature oilfield system and its $16 \mathrm{Sr}$ RNA gene clone library was similar to the sequences retrieved from other high-temperature reservoirs [28,30-35].

\section{Possible growth substrates for microbial communities of petroleum reservoirs}

Crude oil is the main substrate for microorganisms inhabiting the oilfields. Geochemical data indicate that petroleum biodegradation occurs in reservoirs with temperatures not exceeding $80{ }^{\circ} \mathrm{C}$ [36]. This is supported by microbiological investigation of petroleum reservoirs, analysis of the rates of biogenic processes, and research in microbial biology, which confirm that $80-85{ }^{\circ} \mathrm{C}$ is the upper temperature limit for petroleum biodegradation. Under subsurface conditions crude oil biodegradation is usually a slow process. Assuming that biodegradation occurs in the lowest $2 \%$ of the oil column, Head et al. [37] calculated hydrocarbon destruction fluxes at the base of oil columns to be of the order of $10^{-4} \mathrm{~kg}$ hydrocarbons $\mathrm{m}^{-2} \mathrm{yr}^{-1}$ for reservoirs at $40-70{ }^{\circ} \mathrm{C}$.

The probable mechanisms of hydrocarbon degradation to methane in reservoirs were elucidated by Jones et al. [38] in laboratory experiments. In microcosms the hydrocarbon composition of degraded oil and generated gases was monitored, together with the carbon isotopic compositions of gas and oil samples taken at wellheads. Crude-oil hydrocarbon degradation under methanogenic conditions in the laboratory was found to mimic the characteristic sequential removal of compound classes seen in reservoir-degraded petroleum. The initial preferential removal of $n$-alkanes generated the amounts of methane close to stoichiometric ones, principally by hydrogenotrophic methanogenesis. This conclusion was supported by molecular studies of the methanogen community composition in oil-degrading microcosms. As much as $86-87 \%$ of archaeal 16S rRNA genes in clone libraries were close to the 16Sr RNA genes of hydrogenotrophic methanogens. Thus, both the highly enriched $\mathrm{CO}_{2}$ carbon isotopic signatures in heavily degraded oils and laboratory data suggest that methanogenic hydrocarbon degradation occurs predominantly via syntrophic oxidation of alkanes to acetate and hydrogen.

Davydova - Charakhchian et al. [39] were the first to show that acetate in high-temperature oilfield was decomposed by a binary syntrophic association with a lithoautotrophic methanogen Methanothermobacter thermoautotrophicus (Methanobacterium thermoautotrophicum $=M$. thermoalcaliphilum) as the terminal component. The acetate-oxidizing component of this association obtained from the Mykhpaiskoe high- temperature oilfield was not identified. Later Nilsen \& Torsvik [40] observed methane formation in enrichment cultures with acetate at the temperatures of 70,80 , and $92{ }^{\circ} \mathrm{C}$, but attempts to isolate acetate-utilizing methanogens were also unsuccessful. Indication of syntrophic acetate degradation as the main methanogenic pathway in hightemperature Dagang and Shengli oilfields (China) and in Yabase oilfield (Japan) was also obtained [23,33,41].

The process of methane production in formation waters of the Dagang high-temperature petroleum reservoir was registered by radioisotope methods with $\mathrm{NaH}^{14} \mathrm{CO}_{3}$ and ${ }^{14} \mathrm{CH}_{3} \mathrm{COONa}$

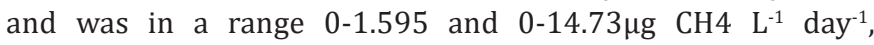
respectively (Table 1). However, pure cultures of thermophilic aceticlastic methanogens were not obtained. It was revealed that in this oilfield aceticlastic methanogenesis was probably not pronounced $[11,33,42]$. Acetate was decomposed to methane and $\mathrm{CO}_{2}$ by a syntrophic association including acetate-degrading bacteria of the Thermoanaerobacter-Caldanaerobacter group, which supplied hydrogen for the $\mathrm{H}_{2}$-utilizing methanogens of the genus Methanothermobacter. Shestakova and co-authors [42] for the first time isolated in pure cultures both components of syntrophic methanogenic associations and identified them as Thermoanaerobacter ethanolicus and Methanothermobacter thermoautotrophicus (and Methanothermobacter wolfeii). Experiments with labelled $2-{ }^{14} \mathrm{C}$ acetate revealed that the binary culture combining T. ethanolicus and M. thermoautotrophicus (or Methanothermobacter wolfeii) carried out the reaction of syntrophic acetate degradation to methane. The data obtained show that syntrophic associations may contribute significantly to methane production in high-temperature petroleum reservoirs. As a result of this study, an important ecological function of fermentative bacteria of the ThermoanaerobacterCaldanaerobacter group was revealed, consisting in their ability to carry out syntrophic acetate oxidation to $\mathrm{H}_{2}$ and $\mathrm{CO}_{2}$, which is then reduced to methane by hydrogenothrophic methanogens.

This work suggests important biogeochemical conclusions. Since methane formation in the presence of acetate may be carried out either by aceticlastic methanogens or by syntrophic 
associations, quantitative assessment of the rates of these processes requires experiments with labeled acetate both without antibiotic, as well as with a penicillin group antibiotic suppressing the growth of bacteria involved in syntrophic acetate oxidation. The difference between these values will indicate the rate of aceticlastic methanogenesis. Quantitative estimation of the rate of syntrophic acetate degradation to methane in petroleum reservoirs is presently not available in the literature.

Hydrogen of biogenic and abiogenic origin, volatile fatty acids (acetate and propionate) and crude oil are the substrates utilized by syntrophic methanogenic communities from petroleum reservoirs, containing methanogens and protonreducing bacteria $[23,38,40]$. Methylated compounds have not yet been investigated as possible substrates for halophilic methanogens in formation water, although methanogenesis on methylamine was detected by the radioisotope method $[43,44]$. Thus, neither true halophilic, nor hyperthermophilic acetateutilizing methanogens were found in petroleum reservoirs.

Pure cultures of mesophilic and thermophilic methanogens utilizing $\mathrm{H}_{2} / \mathrm{CO}_{2}$ have been isolated from petroleum reservoirs $[1,27]$. Acetate-utilizing methanogens have been isolated only from petroleum reservoirs with temperatures not exceeding $50^{\circ} \mathrm{C}$. Aceticlastic methanogens growing at above $80{ }^{\circ} \mathrm{C}$ were not revealed in petroleum reservoirs [28]; they have not been described in the literature. High acetate content in formation waters may result from the rate of its formation as a result of petroleum biodegradation exceeding the rate of consumption. Available data suggest that molecular hydrogen is a major component in the chain of organic matter decomposition at the temperatures exceeding $70^{\circ} \mathrm{C}$. Hydrogenotrophic methanogens, including $M$. thermoautotrophicus, $M$. thermoaggregans, $M$. thermolithotrophicus, Methanothermobacter tenebrarum, or Methanothermobacter crinale could be producers of methane under such conditions $[22,23,33,39,40-42,45-46]$.

In the Bondyuzhskoe petroleum reservoir with a temperature $30-40{ }^{\circ} \mathrm{C}$ and high salinity of formation water, methane was formed mainly from labeled bicarbonate, rather than from acetate $[43,44]$. Methanogenesis was reported at formation water salinity from 15.8 to $274.5 \mathrm{~g} / \mathrm{l}$; increase in salinity resulted in lower methanogenesis rates. Maximum methanogenesis rate of $4.95 \mu \mathrm{g} \mathrm{CH}_{4} \mathrm{~L}^{-1}$ day $^{-1}$ was found in the desalinized water of the near-bottom zone of injection well [44]. The contribution of the acetate methyl group to methane production was between 4 and $26 \%$. Methane was also produced from labeled methylamine; however, the data on the presence of this substrate in the reservoir are not available. Hydrogenotrophic methanogens of the genus Methanobacterium isolated from the Bondyuzhskoe reservoir grew at salinity not exceeding 3\% $\mathrm{NaCl}$ (M. bryantii, M. ivanovii, M. formicicum) or $8 \% \mathrm{NaCl}$ (M. formicicum) [43]. Organotrophic methanogens Methanosarcina mazei and Methanococcoides euhalobius (=Methanohalophilus euhalobius) were most resistant to salt and grew at the total salinity of 100 и $140 \mathrm{~g} / \mathrm{l}$, respectively $[43,47]$.
In formation waters of sandstone oil-bearing collectors of the Kongdian bed of the Dagang high-temperature oilfield (China), sulfate was practically absent. Nevertheless both methanogenesis and sulfate reduction were registered as the terminal process of oil degradation (Table 1). In the course of application of the MEOR technology, based on injection of water-air mixture and nitrogen and phosphorous mineral salts, an increase of sulfate content in formation waters (from 0 to $178 \mathrm{mg} / \mathrm{l})$ was found [11]. Washing of sulfates from the oilbearing rocks was observed earlier by Rozanova and co-authors [12]. We believe that FeS present in oil-bearing rocks could be oxidized by microorganisms in the near-bottom zone of injection wells where oxygen arrives dissolved in injection water and this process (es) resulted in production of sulfate which stimulated sulfate reduction. Ferric iron may act as an electron acceptor for iron-reducing bacteria of the genus Shewanella, which were isolated from the Dagang oilfield [48].

High numbers of cultivable sulfate-reducing or methanogenic microorganisms in formation waters do not necessarily correlate with the rates of microbial processes. This was confirmed by investigation of the formation fluid from production well 10941 of the Kongdian bed of the Dagang oilfield [11,49]. During the application of the MEOR technology, the activation process was completed and the concentrations of substrates required for growth of anaerobic microorganisms were low. Although methanogenesis rate was not registered by radioisotope technique, the number of cultivable methanogens remained high $\left(10^{4}\right.$ cells $\left.\bullet \mathrm{mL}^{-1}\right)$. The number of sulfate-reducing bacteria also reached $10^{5}$ cells $\bullet \mathrm{mL}^{-1}$, although in that period sulfate was absent in formation water and the registered rate of sulfate reduction decreased to zero.

Cultivable sulfate-reducing bacteria may occur in high numbers in formation waters containing no sulfates. It is known that in the presence of sulfate and other oxidized sulfur compounds sulfate-reducing bacteria are able to utilize a range of low-molecular-weight organic compounds (fatty acids, alcohols, lactate, acetate, and pyruvate). Some strains grow on more complex organic compounds, such as indole, phenol, catechol, saturated unbranched hydrocarbons, and alkyl benzenes $[16,20,22]$. A number of strains capable of reducing nitrate, $\mathrm{Fe}^{3+}$, $\mathrm{U}(\mathrm{VI})$, Se (VI), and $\mathrm{Cr}(\mathrm{VI})$ have been isolated. It is important that in the absence of chemical electron acceptors these bacteria are able to grow and to obtain energy from fermentation and interspecies electron transfer using methanogens as a biological acceptor of electrons. In this case, sulfate-reducing bacteria are possibly involved in the carbon cycle and transform hydrocarbons or products of oil degradation together with fermentative and methanogenic microorganisms.

These data especially require consideration when the results of molecular investigation of microbial phylogenetic diversity in petroleum fields are interpreted. Detection of the 16Sr RNA genes or specific functional genes in gene libraries does not confirm the relevant microbial geochemical activity in the 
reservoir. Molecular studies can offer insights into the organisms that may be active in the environment, but they underestimate the complexity and diversity of microbial interactions that are involved in petroleum biodegradation in oil fields.

Jiménez and co-authors [50] investigated in situ biotransformation of oil to methane in the Dagang oilfield using chemical fingerprinting, isotopic analyzes and molecular and biological methods. Geochemical data from oil, water and gas samples taken from the reservoir were consistent with in situ biogenic methane production coupled to the degradation of aliphatic and aromatic hydrocarbons. It was shown that autochthonous microbiota was capable of producing methane from ${ }^{13} \mathrm{C}$ labeled $\mathrm{n}$-hexadecane or 2-methylnaphthalene, and it was suggested that further methanogenesis could occur from the degradation of aromatic and polyaromatic fractions of the Dagang reservoir fluids.

Capacity of methanogenic and sulfate-reducing prokaryotes, responsible for the terminal stages of petroleum biodegradation, to separate (fractionate) the stable isotopes of carbon (ratios of ${ }^{13} \mathrm{C}$ to ${ }^{12} \mathrm{C}, \delta^{13} \mathrm{C}$ ) and sulfur (ratios of ${ }^{34} \mathrm{~S}$ to ${ }^{32} \mathrm{~S}$; $\delta^{34} \mathrm{~S}$ ), respectively is important for the understanding of their geochemical role. Preferential utilization of isotopically light compounds by these microorganisms and formation of methane and sulfide enriched with ${ }^{12} \mathrm{C}$ and ${ }^{32} \mathrm{~S}$, respectively were confirmed by numerous authors $[24,27,38,49,51-53]$. Together with direct measurement of the rates of biogenic processes by radiotracer techniques, comprehensive information on the changes in $\mathrm{pH}$, redox conditions, stable isotope composition, and concentration of individual compounds in formation water, gas and oil (sulfate, carbonate, sulfide, methane, and carbon dioxide, as well as emergence of the products of petroleum degradation) may be used to confirm microbial geochemical activity.

\section{Acetogenesis}

To determine the fraction of total acetate production derived from reduction of carbon dioxide, $\mathrm{NaH}^{14} \mathrm{CO}_{3}$ was added to each water sample assuming that $\mathrm{H}_{2}$ was produced by microorganisms presented in the formation waters $[43,44]$. The production of acetate proceeded in waters from the Bondyuzhskoe oilfield with the salinity up to $237 \mathrm{~g} \mathrm{~L}^{-1}$ at a mean rate of $17 \mu \mathrm{g} \mathrm{L}^{-1}$ day 1 , which is by two orders higher than the methanogenesis and sulfate reduction rates. Higher acetogenesis rates (37$44 \mu \mathrm{g} \mathrm{L}^{-1}$ day $^{-1}$ ) were observed in the low salinity formation waters. Acetogenesis rate in waters from the high-temperature Mykhpaiskoe oilfield was in a range from 6 to $196 \mu \mathrm{g} \mathrm{L}^{-1}$ day $^{-1}$ [44]. Since the rate of acetate destruction was 5 times higher than the rate of acetogenesis, other sources of acetate influx should exist.

\section{Aerobic methane oxidation}

Only few studies were devoted to aerobic methane oxidation in petroleum reservoirs. The rate of aerobic methane oxidation $\left({ }^{14} \mathrm{CH}_{4}\right)$ registered in formation water of the water-flooded petroleum reservoirs located in Tatarstan (Bondyuzhskoe, Romashkinskoe) was as high as $294 \mu \mathrm{L} \mathrm{CH}_{4} \mathrm{~L}^{-1}$ day $^{-1}$ [54-59]. Methane-oxidizing bacteria were concentrated in the bottom zone of injection wells. Aerobic methane oxidation was not detected by radioisotope technique in the zone of production wells with highly mineralized water, probably because of the absence of dissolved oxygen, although viable cells of methaneoxidizing bacteria were present in formation water.

\section{Assimilation of $1-{ }^{14} \mathrm{C}$-octadecane by microorganisms of the oilfield}

Table 2: Chemical characteristics, rates of methanogenesis (MG) and sulfate reduction (SR), and numbers of cultivable microorganisms in production waters from the high-temperature heavy oil Dagang oilfield and incorporation of the labeled $1^{-14} \mathrm{C}$-octadecane in microbial biomass from injection and production waters.

\begin{tabular}{|c|c|c|c|c|c|c|c|c|c|c|c|c|}
\hline \multirow[t]{2}{*}{$\begin{array}{l}\text { Well No., } \\
\text { sample }\end{array}$} & \multicolumn{2}{|c|}{$\begin{array}{l}\text { Activity of microbial biomass } \\
\text { from } 10 \mathrm{ml} \text { of formation of } \\
\text { water }\end{array}$} & \multirow{2}{*}{$\begin{array}{c}\text { Total } \\
\text { salinity, } \\
\text { mg L L }^{-1}\end{array}$} & \multirow{2}{*}{$\begin{array}{c}\mathrm{SO}^{2-}{ }_{4}, \mathrm{mg} \\
\mathrm{L}^{-1}\end{array}$} & \multirow{2}{*}{$\begin{array}{l}\mathrm{HCO}_{3}^{-}, \\
\mathrm{mg} \mathrm{L}^{-1}\end{array}$} & \multirow{2}{*}{$\begin{array}{c}\text { Acetate, } \\
\text { mg L L }^{-1}\end{array}$} & \multirow{2}{*}{$\begin{array}{l}\text { Aerobic } \\
\text { organo- } \\
\text { trophs, } \\
\text { cells } \mathrm{mL}^{-1}\end{array}$} & \multirow{2}{*}{$\begin{array}{l}\text { Sulfate- } \\
\text { reducers, } \\
\text { cells } \mathrm{mL}^{-1}\end{array}$} & \multirow{2}{*}{$\begin{array}{l}\text { Methano- } \\
\text { gens, } \\
\text { growing } \\
\text { on acetate, } \\
\text { cells } \mathrm{mL}^{-1}\end{array}$} & \multicolumn{2}{|c|}{ MG, $\mu$ g of CH4 L $\mathrm{L}^{-1}$ day $^{-1}$} & \multirow[t]{2}{*}{$\begin{array}{c}\text { SR, } \\
\mu \mathrm{g} \text { of } \\
\mathrm{S} 2-\mathrm{L}^{-1} \\
\text { day }^{-1}\end{array}$} \\
\hline & Counts/min & $\%$ & & & & & & & & $\begin{array}{c}\text { From } \\
\mathrm{NaH}^{14} \mathrm{CO}_{3}\end{array}$ & $\begin{array}{c}\text { From } \\
2-{ }^{-14} \mathrm{C} \text {-acetate }\end{array}$ & \\
\hline $\begin{array}{l}\text { Injection } \\
\text { water, } 1^{\text {st }} \\
\text { station }\end{array}$ & $3.6 \cdot 10^{6}$ & 100 & 6062 & 24 & 518 & 5 & $10^{5}$ & $10^{3}$ & $10^{3}$ & $\mathrm{Nd}$ & $\mathrm{Nd}$ & $\mathrm{Nd}$ \\
\hline $1098 *-8 \mathrm{~m} 3$ & $1.3 \cdot 10^{6}$ & 36.1 & 6300 & 12 & 579 & 2.5 & $10^{5}$ & $10^{3}$ & $10^{3}$ & 1.87 & 109.66 & 201.04 \\
\hline \multicolumn{13}{|c|}{ Production Wells } \\
\hline $1017-3$ & $13.9 \cdot 10^{3}$ & 0.39 & 6376 & 12 & 671 & 3 & $10^{2}$ & 10 & 10 & 0.032 & 0.148 & 45.94 \\
\hline 1008 & $13.5 \cdot 10^{3}$ & 0.37 & 6588 & 35 & 549 & 1.2 & $10^{3}$ & 0 & 10 & 0 & 0 & 0.28 \\
\hline $1008-1$ & $12.0 \cdot 10^{3}$ & 0.34 & 6612 & 24 & 701 & 1 & $10^{2}$ & 10 & $10^{3}$ & 11.85 & 0.68 & 6.65 \\
\hline 63 & $8.0 \cdot 10^{3}$ & 0.22 & 6154 & 24 & 549 & 6.4 & 10 & $<10$ & $<10$ & 0.047 & 0 & 15.12 \\
\hline $1050-2$ & $7.9 \cdot 10^{3}$ & 0.22 & 6300 & 35 & 518 & 1.1 & 10 & 0 & $<10$ & 0.033 & 0.001 & 0.172 \\
\hline $1015-1$ & $7.0 \cdot 10^{3}$ & 0.19 & 6454 & 35 & 579 & 0.6 & $10^{5}$ & 0 & $<10$ & 5.762 & 0.008 & 18.95 \\
\hline 1012-1 & $0.4 \cdot 10^{3}$ & 0.01 & 6246 & 24 & 610 & 1.2 & $10^{4}$ & 10 & 103 & 0.750 & 0.055 & 0.88 \\
\hline
\end{tabular}

*Backflushed water from injection well 1098, sample 8 m3. Nd -not determined. 
Assimilation of saturated hydrocarbons by the microbial community of the Dagang high-temperature oil field, which has been exploited with water-flooding over 30 years, was studied using labeled $1^{-14} \mathrm{C}$-octadecane. For analysis, formation water samples from the same horizon and similar in chemical composition were used, as well as injected water. The main difference was in the presence of small amounts of dissolved oxygen in injected water (1.6-2.8mg $\mathrm{O}_{2} / \mathrm{l}$ water) and in the fluid from the near-bottom zone of the injection well $(0.4 \mathrm{mg}$ $\mathrm{O}_{2} / \mathrm{l}$ water), where oxygen arrived with injection water. Potential activity of hydrocarbon-oxidizing microorganisms in different zones of the water-flooded oil field was determined by incorporation of the labeled $1-{ }^{14} \mathrm{C}$-octadecane into microbial biomass. Formation water samples were sealed, avoiding air bubbles, injected with $1^{-14} \mathrm{C}$-octadecane, and incubated for $24 \mathrm{~h}$ at $60{ }^{\circ} \mathrm{C}$. The samples were then fixed with saturated $\mathrm{KOH}$ and filtered through membrane filters $(0.22 \mu \mathrm{m})$. Oil was removed from the filters with chloroform and toluene, and dried filters were immersed in the scintillation liquid with $\beta$-phenylethylamine and methanol (3:1:1). Radioactivity was measured on a 1219 Rackbeta scintillation counter (LKB, Wallac, Turku, Finland). The highest incorporation of radioactive carbon from $1^{-14} \mathrm{C}$-octadecane into the biomass (counts/min) observed in injected water sample was accepted as 100\% (Table 2).

Radioactivity of the biomass from the liquid collected from the near-bottom zone of the injection well was $36.1 \%$, and in water from production wells was in the range of 0.01 $0.39 \%$ from the value for injection water. Incorporation of carbon from $1^{-14} \mathrm{C}$-octadecane into the biomass of the nearbottom zone microorganisms may indicate active hydrocarbon oxidation in the oil field zone supplied with dissolved oxygen, biogenic elements, and enhance water and mass exchange. ${ }^{14} \mathrm{C}$ incorporation into microbial biomass from producing wells may indicate the presence of microorganisms capable of utilizing this hydrocarbon under anoxic conditions. Thus, potential rate of biodegradation of oil $n$-alkanes in a water-flooded oilfield was much higher in the oxidized zone close to injection wells than in the anoxic zone, where dissolved oxygen was absent.

\section{Conclusion}

Understanding of diversity and functioning of oil field microbial communities will lead to deeper and more accurate prediction of the processes in this ecosystem and possibly to intentional control of these processes. Development of modern biotechnologies for enhanced oil recovery, suppression of sulfidogenic populations and corrosion of metal equipment, improvement of oil quality, and conversion of residual oil to methane require comprehensive investigation of the microorganisms in petroleum reservoirs. The application of radioisotope approach, together with geochemical analysis of the environment, methods of analysis of stable isotope composition, cultivation methods and molecular studies of microbial communities are necessary tools for understanding microbial processes in petroleum reservoirs.

\section{Acknowledgment}

This work was supported by the Russian Science Foundation (grant no. 16-14-00028).

\section{References}

1. Magot M, Ollivier B, Patel BK (2000) Microbiology of petroleum reservoirs. Antonie van Leeuwenhoek 77(2): 103-116.

2. Youssef N, Elshahed MS, McInerney MJ (2009) Microbial processes in oil fields: Culprits, problems and opportunities. Adv Appl Microbiol 66: 141-251.

3. Ivanov MV (1956) Application of isotopes for the study of sulfate reduction processes in Lake Belovod. Mikrobiologiya 25: 301-313.

4. Belyaev SS, Ivanov MV (1975) Radioisotopic method for determination of the intensity of bacterial methane production. Mikrobiologiya 44(1): 166-168.

5. Laurinavichus KS, Belyaev SS (1978) Determination of the intensity of microbial methane production by the radioisotopic method. Microbiology (English translation of Mikrobiologiya) 47: 1115-1117.

6. Rozanova EP, Mehtieva NA, Alieva NSh (1969) Microbiological processes and corrosion of metal equipment in water-flooded oilfield. Mikrobiologiya 38: 860-867.

7. Nazina TN, Rozanova EP, Kuznetsov SI (1985) Microbial oil transformation processes accompanied by methane and hydrogensulfide formation. Geomicrobiol J 4(2): 103-130.

8. Nazina TN, Ivanova AE, Borzenkov IA, Belyaev SS, Ivanov MV (1995) Occurrence and geochemical activity of microorganisms in hightemperature water-flooded oil fields of Kazakhstan and Western Siberia. Geomicrobiol J 13(3): 181-192.

9. Nazina TN, Ivanova AE, Golubeva OV, Ibatullin RR, Belyaev SS, et al (1995) Occurrence of sulfate- and iron-reducing bacteria in stratal waters of the Romashkinskoe oil field. Microbiology (Mikrobiologiya) 64(2): 245-251.

10. Nazina TN, Xue YF, Wang XY, Grigoriyan AA, Ivoilov VS, et al. (2000) Diversity and activity of microorganisms in the Daqing oil field of China and their potential for biotechnological applications. Resource \& Environ Biotechnol 3(2-3): 161-172.

11. Nazina TN, Grigor'yan AA, Shestakova NM, Babich TL, Pavlova NK, et al. (2008) MEOR study enhances production in a high-temperature reservoir. World Oil June 97-101.

12. Rozanova EP, Bykov VN, Baldina AL, Kosogorova TA (1976) Biogenous elements and sulfate reduction in watered oil carbonate layer. Mikrobiologiya 45: 318-322.

13. Nazina TN, Ivanova AE, Ivoilov VS, Miller YuM, Ibatullin RR, et al. (1998) Microbiological and geochemical characterization of carbonate oil collectors of Tatarstan. Microbiology (Mikrobiologiya) 67(5): 575581.

14. Nazina TN, Ivanova AE, Ivoilov VS, Miller YuM, Kandaurova GF, et al. (1999) Results of the trial of the microbiological method for the enhancement of oil recovery at the carbonate collector of the Romashkinskoe oil field: Biogeochemical and production characteristics. Microbiology (Mikrobiologiya) 68(2): 222-226.

15. Nazina TN, Shestakova NM, Pavlova NK, Tatarkin YV, Ivoilov VS, et al (2013) Functional and phylogenetic microbial diversity in formation waters of a low-temperature carbonate petroleum reservoir. Int Biodeterior Biodegrad 81: 71-81.

16. Davidova IA, Duncan KE, Choi OK, Suflita JM (2006) Desulfoglaeba alkanexedens gen. nov., sp. nov., an n-alkane-degrading, sulfatereducing bacterium. Int J Syst Evol Microbiol 56(12): 2737-2742. 


\section{Advances in Biotechnology \& Microbiology}

17. Gieg LM, Jack TR, Foght JM (2011) Biological souring and mitigation in oil reservoirs. Appl Microbiol Biotechnol 92(2): 263-282.

18. Khelifi N, Grossi V, Hamdi M, Dolla A, Tholozan J, et al. (2010) Anaerobic oxidation of fatty acids and alkenes by the hyperthermophilic sulfatereducing archaeon Archaeoglobus fulgidus. Appl Environ Microbiol 76(9): 3057-3060.

19. Aeckersberg F, Bak F, Widdel F (1991) Anaerobic oxidation of saturated hydrocarbons to $\mathrm{CO} 2$ by a new type of sulfate-reducing bacterium. Arch Microbiol 156(1): 5-14.

20. Widdel F, Rabus R (2001) Anaerobic biodegradation of saturated and aromatic hydrocarbons. Curr Opin Biotech 12(3): 259-276.

21. Widdel F, Musat F, Knittel K, Galushko A (2007) Anaerobic degradation of hydrocarbons with sulphate as electron donor. In: Barton LL and Hamilton WA (Eds.), Sulphate-reducing Bacteria. Environmental and Engineered Systems. Cambridge University Press, Cambridge, UK, pp. 265-303.

22. Mbadinga SM, Wang L-Y, Zhou L, Liu J-F, Gu J-D, Mu B-Z (2011) Microbial communities involved in anaerobic degradation of alkanes. Int Biodeterior Biodegrad 65(1): 1-13.

23. Mbadinga S, Li KP, Zhou L, Wang LY, Yang SZ, et al. (2012) Analysis of alkane-dependent methanogenic community derived from production water of a high-temperature petroleum reservoir. Appl Microbiol Biotechnol 96(2): 531-542.

24. Rozanova EP, Borzenkov IA, Tarasov AL, Suntsova LA, Belyaev SS, et al. (2001) Microbiological processes in a high-temperature oil field. Microbiology (Mikrobiologiya) 70(1): 102-110.

25. Callaghan AV, Davidova IA, Savage-Ashlock K, Parisi VA, Gieg LM, et al. (2010) Diversity of benyzl- and alkylsuccinate synthase genes in hydrocarbon-impacted environments and enrichment cultures. Environ Sci Technol 44(19): 7287-7294.

26. Belyaev SS, Laurinavichus KS, Obraztsova AYa, Gorlatov SN, Ivanov MV (1982) Microbiological processes in the near-bottom zone of injection wells of oil fields. Microbiology (Mikrobiologiya) 51: 997-1001.

27. Belyaev SS, Wolkin R, Kenealy WR, DeNiro MJ, Epstein S, et al. (1983) Methanogenic bacteria from the Bondyuzhskoe oil field: general characterization and analysis of stable-carbon isotopic fractionation. Appl Environ Microbiol 45: 691-697.

28. Bonch Osmolovskaya EA, Miroshnichenko ML, Lebedinsky AV, Chernyh NA, Nazina TN, et al. (2003) Radioisotopic, culture-based and oligonucleotide microchip analyses of thermophilic microbial communities in a continental high-temperature petroleum reservoir Appl Environ Microbiol 69(10): 6143-6151.

29. Nazina TN, Pavlova NK, Ni F, Shestakova NM, Ivoilov VS, et al. (2008) Regulation of geochemical activity of microorganisms in a petroleum reservoir by injection of $\mathrm{H} 2 \mathrm{O} 2$ or waterair mixture. Microbiology (Mikrobiologiya) 77(3): 324-333.

30. Orphan VJ, Goffredi SK, Delong EF, Boles JR (2003) Geochemical influence on diversity and microbial processes in high-temperature oil reservoirs. Geomicrobiol J 20(4): 295-311.

31. Orphan VJ, Taylor LT, Hafenbradl D, Delong EF (2000) Culturedependent and culture-independent characterization of microbial assemblages associated with high-temperature petroleum reservoirs. Appl Environ Microbiol 66(2): 700-711.

32. Gieg LM, Davidova IA, Duncan KE, Suflita JM (2010) Methanogenesis, sulfate reduction and crude oil biodegradation in hot Alaskan oilfields. Environ Microbiol 12(11): 3074-3086.

33. Nazina TN, Shestakova NM, Grigor'yan AA, Mikhailova EM, Turova TP, et al. (2006) Phylogenetic diversity and activity of anaerobic microorganisms of high-temperature horizons of the Dagang Oilfield (China). Microbiology (Mikrobiologiya) 75(1): 70-81.
34. Li H, Yang SZ, Mu BZ, Rong ZF, Zhang J (2007) Molecular phylogenetic diversity of the microbial community associated with a hightemperature petroleum reservoir at an offshore oilfield. FEMS Microbiol Ecol 60(1): 74-84.

35. Gittel A, Sorensen KB, Skovhus TL, Ingvorsen K, Schramm A (2009) Prokaryotic community structure and sulfate reducer activity in water from high-temperature oil reservoirs with and without nitrate treatment. Appl Environ Microbiol 75(22): 7086-7096.

36. Wilhelms A, Larter SR, Head I, Farrimond P, Di-Primio R, et al. (2001) Biodegradation of oil in uplifted basins prevented by deep-burial sterilization. Nature 411: 1034-1037.

37. Head IM, Jones DM, Larter SR (2003) Biological activity in the deep subsurface and the origin of heavy oil. Nature 426(6964): 344-352.

38. Jones DM, Head IM, Gray ND, Adams JJ, Rowan AK, et al. (2008) Crudeoil biodegradation via methanogenesis in subsurface petroleum reservoirs. Nature 451(7175): 176-180.

39. Davydova-Charakhch'yan IA, Kuznetsova VG, Mityushina LL, Belyaev SS (1992) Methane-forming bacilli from oil fields of Tatarstan and Western Siberia. Microbiology (Mikrobiologiya) 61: 299-305.

40. Nilsen RK, Torsvik T (1996) Methanococcus thermolithotrophicus isolated from North Sea oil field reservoir water. Appl Environ Microbiol 62(2): 728-731.

41. Mayumi D, Mochimaru H, Yoshioka H, Sakata S, Maeda H, et al. (2011) Evidence for syntrophic acetate oxidation coupled to hydrogenotrophic methanogenesis in the high-temperature petroleum reservoir of Yabase oil field (Japan). Environ Microbiol 13(8): 1995-2006.

42. Shestakova NM, Ivoilov VS, Tourova TP, Belyaev SS, Poltaraus AB, et al (2011) Application of Clone Libraries: Syntrophic Acetate Degradation to Methane in a High-Temperature Petroleum Reservoir: CultureBased and 16SrRNA Genes Characterization. In: Whitby C and Lund Skovhus T (Eds.), Applied Microbiology and Molecular Biology in Oilfield Systems. Proceedings from the International Symposium on Applied Microbiology and Molecular Biology in Oil Systems (ISMOS-2), 2009. Springer Netherlands, Netherlands, pp. 45-53.

43. Borzenkov IA, Belyaev SS, Miller YuM, Davydova IA, Ivanov MV (1997) Methanogenesis in the highly mineralized stratal waters of the Bondyuzhskoe oil field. Microbiology (Mikrobiologiya) 66: 104-110.

44. Belyaev SS, Borzenkov IA (1993) Microbial transformation of lowmolecular-weight carbon compounds in the deep subsurface. In: Biogeochemistry of global change. NY-London: Chapman \& Hall 825838.

45. Nakamura K, Takahashi A, Mori C, Tamaki H, Mochimaru H, et al (2013) Methanothermobacter tenebrarum sp. nov., a hydrogenotrophic thermophilic methanogen isolated from gas-associated formation water of a natural gas field. Int J Syst Evol Microbiol 63(2): 715-722.

46. Cheng L, Dai L, Li X, Zhang H, Lu Y (2011) Isolation and characterization of Methanothermobacter crinale sp. nov, a novel hydrogenotrophic methanogen from Shengli oil field. Appl Environ Microbiol 77: 52125219 .

47. Obraztsova AY, Shipin OV, Bezrukova LV, Belyaev SS (1987) Properties of the coccoid methylotrophic methanogen Methanococcoides euhalobius sp. nov. Microbiology (Mikrobiologiya) 56: 523-527.

48. Shestakova NM, Korshunova AV, Mikhailova EM, Sokolova DSh Tourova TP, et al. (2011) Characterization of the aerobic hydrocarbonoxidizing enrichments from a high-temperature petroleum reservoir by comparative analysis of DNA- and RNA-derived clone libraries. Microbiology [English translation of Mikrobiologiya] 80(1): 60-69.

49. Nazina TN, Ivanova AE, Ivoilov VS, Miller YuM, Kandaurova GF, et al. (1999) Results of the trial of the microbiological method for the enhancement of oil recovery at the carbonate collector of the Romashkinskoe oil field: Biogeochemical and production 
characteristics. Microbiology (Mikrobiologiya) 68(2): 222-226.

50. Jiménez N, Morris BEL, Cai M, Gründger F, Yao J, et al. (2012) Evidence for in situ methanogenic oil degradation in the Dagang oil field. Org Geochem 52: 44-54.

51. Ivanov MV, Belyaev SS, Laurinavichus KK, Obraztsova AYA, Gorlatov SN (1982) Distribution and geochemical activity of microorganisms in a water-flooded oil field. Microbiology (Mikrobiologiya) 51(2): 336-341.

52. Frazer LC, Bolling JD (1991) Hydrogen sulfide forecasting techniques for the Kuparuk River field. SPE 22105: 399-406.

53. Cavallaro AN, Gracia Martinez ME, Ostera H, Panarello H, Cordero RR (2005) Oilfield reservoir souring during waterflooding: a case study with low sulphate concentration in formation and injection waters SPE 92959: 1-12.

54. Borzenkov IA, Telitchenko MM, Milekhina EI, Belyaev SS, Ivanov, MV (1991) Methane-oxidizing bacteria and their activity in formation waters of oil fields in Tatar SSR. Microbiology (Mikrobiologiya) 60(3): 558-564.

55. Rozanova EP, Savvichev AS, Karavaiko SG, Miller YuM (1995) Microbial processes in the Savuiskoe oil field in the Ob' region. Microbiology (Mikrobiologiya) 64: 85-90.
56. Rozanova EP, Savvichev AS, Miller YM, Ivanov MV (1997) Microbial processes in a West Siberian oil field flooded with waters containing a complex of organic compounds. Microbiology (Mikrobiologiya) 66: 852-859.

57. Nazina TN, Xue YF, Wang XY, Belyaev SS, Ivanov MV (2000) Microorganisms of the high-temperature Liaohe oil field of China and their potential for MEOR. Res Environ Biotechnol 3: 109-120.

58. Tarasov AL, Borzenkov IA, Milekhina EI, Belyaev SS, Ivanov MV (2002) Dynamics of microbial processes in the stratal waters of the Romashkinskoe oil field. Microbiology (Mikrobiologiya) 71(6): 735742 .

59. Nazina TN, Grigor'yan AA, Shestakova NM, Babich TL, Ivoilov VS, et al. (2007) Microbiological investigations of high-temperature horizons of the Kongdian petroleum reservoir in connection with field trial of a biotechnology for enhancement of oil recovery. Microbiology (Mikrobiologiya) 76(3): 287-296.

\section{Your next submission with Juniper Publishers} will reach you the below assets

- Quality Editorial service

- Swift Peer Review

- Reprints availability

- E-prints Service

- Manuscript Podcast for convenient understanding

- Global attainment for your research

- Manuscript accessibility in different formats ( Pdf, E-pub, Full Text, Audio)

- Unceasing customer service

Track the below URL for one-step submission https://juniperpublishers.com/online-submission.php 